\title{
Living arrangements and food security of a sample of older Palestinian refugees in Lebanon
}

\author{
Nadine R. Sahyoun ${ }^{1}$, Anniebelle Sassine ${ }^{2}$, Anna Vaudin ${ }^{1}$, Fayrouz Sakr-Ashour ${ }^{1}$, Hala Ghattas ${ }^{3}$ \\ 1 Department of Nutrition and Food Science, University of Maryland, College Park, Maryland, USA, 2 American University of Beirut, Beirut, Lebanon; \\ Imperial College, London, UK, ${ }^{3}$ American University of Beirut, Beirut, Lebanon \\ Keywords: food security, living arrangements, palestinian refugees, older adults, poverty
}

https://doi.org/10.29392/001c.13070

\section{Journal of Global Health Reports}

Vol. 4, 2020

\section{Background}

Although we know of the relationship between food insecurity, poor dietary intake and health outcomes, there are limited studies examining the determinants of food insecurity in older adults in developing countries. This study describes the living arrangement and characteristics of protracted Palestinian refugees in Lebanon aged 60 years and older and, the status and determinants of household food insecurity.

\section{Methods}

Two surveys, representative of Palestinian refugees in Lebanon (2010 and 2015), were appended and used to examine living arrangement of older adults and household food security. Our final pooled sample included 5412 households and 24,540 individuals. Of these individuals, $10.85 \%$ ( $\mathrm{n}=2663)$ were adults aged 60 years and older, our population of interest. Living arrangement included 1) households with no older adults, 2) multigenerational households that included at least one older adult, 3) older adults living alone, with spouse or with another older person (single households). Food security was collected using two similar questionnaires that were equated and scores were used to classify households into food secure, moderately and severely food insecure. Means and proportions were used to examine household characteristics and sociodemographic and health variables of older adults by living arrangements. Logistic regression tested determinants of food insecurity.

\section{Results}

About $27 \%$ of older adults lived in single households and of those living alone, $94.3 \%$ were women. Overall, poverty was highly prevalent in households (57\%) and only $38 \%$ of households were food secure. However, poverty and food insecurity were significantly less prevalent in single households $(\mathrm{P}<0.0001)$ and these were also the highest recipients of welfare and remittances.

\section{Conclusions}

Successful interventions to address poverty and food insecurity will require a better understanding of family structure, interactions within the household, and the role that older adults play within the family.

The older adult population is growing rapidly worldwide. Globally, this population is projected to increase from the current 8.5 percent of the population aged 65 and older to 16.7 percent by 2050 . Life expectancy is also projected to increase by 8 years with an estimated 80 percent of older people living in developing countries. ${ }^{1}$ Arab countries are no exception to these projected demographic changes. So far, these countries' populations consist of predominantly younger people, but individuals aged 65 and older will significantly increase by 2050.1,2 This will also apply to the protracted (long-term) Palestinian refugee population living in Lebanon. ${ }^{3}$
Palestinians are the longest and largest refugee group in the world. ${ }^{4}$ A substantial influx of Palestinians sought refuge in Lebanon after their forced displacement in 1948; others followed after the 1967 regional war. They are a unique refugee population because they have lived in camps and in surrounding gatherings serviced by the United Nations Relief and Works Agency (UNRWA) for at least 50 years, with many families having lived there for more than 70 years. Due to their protracted situation, multigenerational families have grown in these camps and settled into their own way of life.

However, Palestinian refugees in Lebanon are a margin- 
alized population, living under difficult conditions because the country has restrictive policies regarding work and internal mobility. These limited employment opportunities have encouraged outmigration of young adults, ${ }^{3}$ with potential consequences for older adults who stay behind. Due to the unique characteristics of this population, it is difficult to compare them to other refugee populations who were internally displaced or migrated to other developing or developed countries. Instead, their living arrangements, despite the restrictions imposed on them by the host country, are somewhat similar to those in neighboring countries with shared values and traditions.

In most Arab countries, older adults are respected members of society and an integral part of the family. They often live in an extended family unit where they contribute to child care and household chores. ${ }^{5}$ However, this contribution by older adults may be jeopardized by the development of poor health and its consequent physical and financial dependence. For example, non-communicable chronic diseases have become the leading cause of morbidity and mortality in Arab countries. ${ }^{6}$ Older adults, generally, are at an increased risk of developing multiple chronic conditions which may place a heavy economic and emotional burden on individuals and their families who care for them and, on society and its health care system. Palestinian refugees in Lebanon face similar risks but require a different analysis as a result of their status which limits work and mobility.

Risk factors including poor dietary intake play a major role in the onset of certain chronic health conditions, such as, cardiovascular disease and stroke. ${ }^{7}$ Food insecurity is at the core of poor diet quality and hence a contributing factor to the onset and deterioration of chronic health conditions. ${ }^{8}$ Food security "exists when all people, at all times, have physical, social and economic access to sufficient, safe and nutritious food which meets their dietary needs and food preferences for an active and healthy life". ${ }^{9}$ Although we know of the relationship between food insecurity, poor dietary intake and health outcomes, as far as we know there is no information on the prevalence and determinants of food insecurity of older adults in Arab countries or in Palestinian refugee camps. Older adults are frequently not the target of surveys or of intervention studies. For example, a study by Sibai et al., showed that although there has been a significant increase in studies on health, and a somewhat smaller increase in diet and nutrition studies over the last decade compared to the previous decade in the Arab region, the absolute number of research studies on older adults in developing countries remains small. ${ }^{10}$

The increasing size of the older adult population and our better understanding of changing needs with age warrants expanding our research to target older adults, especially among Palestinian refugees in Lebanon to address their particular health issues. With appropriate interventions based on such research, people may be able to age successfully, continue to contribute to society and to the family, and decrease healthcare expenditure. This may also have a ripple effect on the younger population and children in a household because of the interdependence of older adults and other members of a household. 5,11,12 Therefore, to fill some of the gaps, this study was undertaken to examine: 1) living arrangements of protracted older Palestinian refugees in Lebanon, 2) characteristics of households and of older individuals by living arrangement, 3) status of household food security by living arrangement and 4) determinants of household food insecurity.

\section{METHODS}

\section{PARTICIPANTS AND STUDY DESIGN}

This is a secondary analysis of data collected from two surveys of representative samples of Palestinian refugees living in Lebanon. The surveys were administered by the American University of Beirut and funded by UNRWA. 3,11 These two surveys were conducted in 2010 and 2015 to document the socioeconomic status and living conditions of protracted Palestinian refugees living in Lebanon in camps and gatherings. Gatherings are neighborhoods of at least 25 households of Palestinians located outside the camps in a geographically defined area. These surveys used a stratified multi-stage cluster sampling approach and households were sampled from the 12 camps and 20 of the 187 gatherings. Details of the surveys are described elsewhere. ${ }^{3,11}$

Within each household, the person responsible for food preparation was invited to participate in a face-to-face interview. In the absence of this person, an available adult family member was interviewed. The interviewees gave written or oral informed consent. In the 2010 and 2015 surveys, 2501 households which included 11,123 individuals and 2969 households with 13,417 individuals, respectively, consented to be interviewed. Our variables of interest, living arrangement and household food security, were similar in both years of the survey and, therefore, the 2 years of data were appended. Data from households with missing information to an item of the food security tool were excluded from the analysis $(n=57)$. Our final pooled sample included 5412 households and 24,540 individuals. Of these individuals, 2663 (10.85\%) were aged 60 years and older, our population of interest.

The research design for both surveys was approved by the Institutional Review Board of the American University of Beirut. The questionnaires used in both surveys were similar. The original questionnaire was translated from English to the local Arabic dialect. All questions were discussed with informants from the Palestinian community and modified based on feedback received. ${ }^{3}$

\section{SOCIODEMOGRAPHIC VARIABLES}

Respondents provided information on the gender, age, marital status, educational attainment, employment status, presence of chronic and acute health conditions and disability of all members of the household. Also obtained, was the relationship of each member to the head of household. Age was treated as a continuous variable, marital status was categorized as married vs unmarried (single, divorced, widowed), educational attainment was categorized as no schooling/didn't complete primary level, completed primary level and, education above primary level. Presence of chronic conditions (such as hypertension, diabetes, cancer, heart problems and stroke) and acute disease and disability were ascertained with a yes/no answer but the recall period for acute illness was limited to within the last six months. 
Table 1. Food security questionnaires used in the 2010 and 2015 surveys of Palestinian refugees in Lebanon

\begin{tabular}{|c|c|c|}
\hline Item label & Food security questionnaire used in 2010 survey & $\begin{array}{l}\text { Food security questionnaire used in } 2015 \\
\text { survey (Arab family food security scale) }\end{array}$ \\
\hline $\begin{array}{l}1 . \\
\text { Inadequate } \\
\text { quality food } \\
\text { (food } \\
\text { sufficiency } \\
\text { question)* }\end{array}$ & $\begin{array}{l}\text { Which of these sentences applies the most to the food eaten by } \\
\text { your household during the past } 6 \text { months? } \\
\text { - We had enough to eat of the kinds of food we wanted } \\
\text { - We had enough to eat but not always the kinds of food we wanted } \\
\text { - Sometimes we did not have enough to eat } \\
\text { - Often we did not have enough to eat }\end{array}$ & $\begin{array}{l}\text { Which of these sentences applies the } \\
\text { most to the food eaten by your household } \\
\text { during the past } 6 \text { months? } \\
\text { - We had enough to eat of the kinds of food } \\
\text { we wanted } \\
\text { - We had enough to eat but not always the } \\
\text { kinds of food we wanted } \\
\text { - Sometimes we did not have enough to eat } \\
\text { - Often we did not have enough to eat }\end{array}$ \\
\hline $\begin{array}{l}2 . \\
\text { Concerned } \\
\text { food would } \\
\text { run out }\end{array}$ & & $\begin{array}{l}\text { In the last } 6 \text { months, was there a time } \\
\text { when you were concerned that you would } \\
\text { run out of food for your household for the } \\
\text { next month? (Yes/No) }\end{array}$ \\
\hline $\begin{array}{l}\text { 3. Food } \\
\text { bought } \\
\text { didn't last† }\end{array}$ & $\begin{array}{l}\text { Tell me if this statement applies to you most of the time, } \\
\text { sometimes, or never: "The food that we bought did not last us and } \\
\text { we didn't have money to buy more" }\end{array}$ & $\begin{array}{l}\text { In the past } 6 \text { months, has it ever happened } \\
\text { that the food you bought was not enough } \\
\text { and you didn't have money to buy more? } \\
\text { (Yes/No) }\end{array}$ \\
\hline $\begin{array}{l}\text { 4. Not } \\
\text { enough of } \\
\text { some foods }\end{array}$ & $\begin{array}{l}\text { Are there any foods you feel your family does not eat enough of? } \\
\text { (Yes/No) If yes, specify: }\end{array}$ & $\begin{array}{l}\text { Were there any foods you feel your family } \\
\text { did not eat enough of in the last } 6 \text { months? } \\
\text { (Yes/No) If yes, specify: }\end{array}$ \\
\hline $\begin{array}{l}\text { 5. Cut size } \\
\text { of meal† }\end{array}$ & $\begin{array}{l}\text { In the past } 6 \text { months, did you or any other adult in your household } \\
\text { ever cut the size of your meal because there was not enough } \\
\text { food? (Yes, almost every month, yes, but not every month, yes in } \\
\text { only } 1 \text { or } 2 \text { months, never) }\end{array}$ & $\begin{array}{l}\text { In the past } 6 \text { months, did you or any other } \\
\text { adult in your household ever cut the size } \\
\text { of your meal because there was not } \\
\text { enough food? (Yes/No) }\end{array}$ \\
\hline $\begin{array}{l}\text { 6. Skipped } \\
\text { meal† }\end{array}$ & $\begin{array}{l}\text { In the past } 6 \text { months, did you or any other household members } \\
\text { ever skip a meal because there was not enough food? (Yes, almost } \\
\text { every month, yes, but not every month, yes in only } 1 \text { or } 2 \text { months, } \\
\text { never) }\end{array}$ & $\begin{array}{l}\text { In the past } 6 \text { months, did you or any other } \\
\text { household members ever skip a meal } \\
\text { because there was not enough food? (Yes/ } \\
\text { No) }\end{array}$ \\
\hline $\begin{array}{l}\text { 7. Did not } \\
\text { eat whole } \\
\text { day or went } \\
\text { to bed } \\
\text { hungry† }\end{array}$ & $\begin{array}{l}\text { In the past } 6 \text { months did you or any member in your household } \\
\text { not eat for a whole day or go to bed hungry because there was not } \\
\text { enough food? (Yes, almost every month, yes, but not every month, } \\
\text { yes in only } 1 \text { or } 2 \text { months, never) }\end{array}$ & $\begin{array}{l}\text { In the past } 6 \text { months did you or any } \\
\text { member in your household not eat for a } \\
\text { whole day or go to bed hungry because } \\
\text { there was not enough food? (Yes/No) }\end{array}$ \\
\hline
\end{tabular}

* Item 1 - Coded as affirmative for all responses except the first.

tItems 3,5,6,7 - Coded as affirmative for any of the yes responses.

The interviewees were asked additional questions about household income, welfare assistance, food-related assets, and total household expenditure, including percent expenditure on food and health. Expenditures were divided by the number of people living in each household to obtain the per person expenditure. Poverty was calculated based on minimal livelihood requirements of household expenditure on food and non-food items and was evaluated against the inflation-adjusted poverty line per adult equivalent. ${ }^{3}$ The poverty line used was US $\$ 6.00$ per day in 2010 , and US $\$ 6.80$ in 2015. Interviewees were asked if the household received welfare assistance which is provided by UNRWA to vulnerable families (yes/no). A food-related assets scale was developed based on the ownership of an oven, microwave, refrigerator and freezer, with each asset contributing one point to the food-related asset scale (score $0-4$ ). This variable was examined as continuous in the regression model.

\section{FOOD SECURITY TOOL}

Interviewees were administered a household food security module. A slightly different tool was used in the 2010 and 2015 surveys (Table 1). These food security tools are described in details elsewhere. ${ }^{12}$ The two food security scales were equated using item response theory models, and households were classified into three levels of food security; food secure (0-1), moderately food insecure (2-4), severe food insecure (5-7). ${ }^{12}$

\section{LIVING ARRANGEMENT}

Households were classified by living arrangements as follows: i) Households that did not include an older adult aged 60 and older, ii) Multigenerational households that included at least one older adult, and iii) Single generation households with an older adult living alone, with another older person or with a spouse. This latter classification is referred 
to as 'single households' for the remainder of this article.

\section{STATISTICAL ANALYSIS}

Data from the two survey years were appended and weights were used to adjust for the complex survey design. Descriptive statistics, using means and proportions, were used to examine the demographic and health variables of all older adults and of older adults by living arrangements. We also examined household socioeconomic status, food security and expenditure on healthcare and on food for all households and for households by living arrangement. We used SAS (version 9.2, SAS Institute Inc, Cary, NC, USA) to analyze the data and generate weighted estimates for the means and proportions. Rao-Scott adjusted chi-square $\left(\chi^{2}\right)$ tests and t-tests were used to test for significant differences in categorical and continuous variables, respectively, between groups. The level of significance was set to $P<0.05$ and multiple pairwise comparisons were adjusted using the Bonferroni correction method. Logistic regression models were used to test the associations between food security and living arrangements controlling for socioeconomic and health characteristics of older adults. In the regression models, food security, as the dependent variable, was coded as food secure (0-1) versus food insecure (2-7). The models were adjusted for the complex survey design and household identification number was included as a cluster effect. The survey years were also included in the model as dummy variables. The sample size for the regression analysis was 2368 individuals as 295 observations were excluded due to missing data primarily for the variables poverty and education.

\section{RESULTS}

\section{LIVING ARRANGEMENT AND CHARACTERISTICS OF HOUSEHOLDS}

Most households did not include older adults (62.3\%) and these households had a significantly higher number of residents. Most older adults lived in multigenerational households (27.9\%) versus living in single households (9.7\%) (Table 2). Overall, poverty was quite prevalent among Palestinian refugees living in Lebanon with more than half of the households living in poverty $(57.0 \%)$. Poverty was significantly lower $(P<0.01)$ in single households $(25.5 \%)$ compared to households with or without an older adult $(60.0 \%$ and $60.6 \%$ respectively). Significantly more single households received welfare $(P<0.01)$ and remittance or financial aid $(P<0.01)$ and, these households spent significantly more per person on healthcare and on food than the other two types of households $(P<0.01)$. Also, multigenerational households with older adults spent significantly more on healthcare and on food per person than households with no older adults $(P<0.01)$ and significantly more received welfare and remittances $(P<0.01)$. Food expenditure as a percentage of total household expenditure was similar for households with and without an older adult $(41.4 \%$ and $40.8 \%$, respectively) compared to $37.1 \%$ in single households (data not shown). There were no significant differences in number of food assets by living arrangements (Table 2).

\section{CHARACTERISTICS OF OLDER ADULTS}

Only $10.85 \%(n=2663)$ of the Palestinian refugee population in Lebanon were aged 60 years and older; the average age of older Palestinians was 69.7 years. Older adults living in single households had a significantly higher mean age than those living in a multigenerational family (71.3 vs 69.1 years) $(P<0.0001)$ and they were significantly more likely to be women $(P<0.001)$ (Table 3$)$. About a third of the single households (36\%) were composed of an individual living alone and of those living alone, $94.3 \%$ were women (data not shown). The remaining single households were composed of two older adults living together; $58 \%$ were married couples, whereas $5.7 \%$ were other relations. 
Table 2. Weighted characteristics of all households, households with no older adult(s),

multigenerational households with at least one older adult (aged 60 and over), households of older adults living alone, with spouse or with another older adult (single households)

\begin{tabular}{|c|c|c|c|c|c|}
\hline & \multirow{2}{*}{$\mathrm{n}$} & \multirow{2}{*}{ All Households } & \multicolumn{3}{|c|}{ Household Living Arrangements } \\
\hline & & & No older adults ( $n=3392)$ & Multigenerational Households $(\mathrm{n}=1495)$ & Single Households $(n=525)$ \\
\hline Household living arrangement (\%) & 5412 & 100 & 62.3 & 27.9 & 9.7 \\
\hline Number of people living in household (mean, (SD)) ${ }^{*}$ & 5412 & $4.5(0.03)$ & $5.0(0.04)^{\mathrm{a}}$ & $4.4(0.06)^{b}$ & $1.5(0.02)^{c}$ \\
\hline Poverty $\left.{ }^{*} \%, \mathrm{Cl}\right)$ & 5068 & $57.0(55.6-58.5)$ & $60.6(58.7-62.4)^{\mathrm{a}}$ & $60.0(57.3-62.8)^{a}$ & $25.5(21.3-29.7)^{b}$ \\
\hline Receiving welfare $(\%$ yes, (CI)) & 5394 & $44.3(42.9-45.7)$ & $39.3(37.5-41.1)^{a}$ & $49.2(46.4-51.9)^{b}$ & $61.8(57.3-66.3)^{c}$ \\
\hline $\begin{array}{l}\text { Receiving remittance from family or aid other than } \\
\text { UNRWA }(\% \text { yes, (CI)) }\end{array}$ & 5401 & $36.5(35.1-37.9)$ & $27.0(25.3-28.6)^{\mathrm{a}}$ & $46.3(43.5-49.1)^{b}$ & $69.1(64.9-73.3)^{\mathrm{c}}$ \\
\hline Number of food-related asset scaleł (mean, (SD)) & 5412 & $2.18(0.01)$ & $2.19(0.01)^{\mathrm{a}}$ & $2.19(0.02)^{a}$ & $2.09(0.03)^{a}$ \\
\hline $\begin{array}{l}\text { Health care expenditure /month in US } \$ \text { / Per person* } \\
\text { (mean, (SD)) }\end{array}$ & 4865 & $27.8(1.0)$ & $16.7(0.7)^{\mathrm{a}}$ & $32.6(1.3)^{b}$ & $82.8(7.9)^{\mathrm{c}}$ \\
\hline Food expenditure/month in US $\$$ / Per person* (mean, (SD)) & 5043 & $73.22(0.76)$ & $66.54(0.85)^{\mathrm{a}}$ & $72.77(1.27)^{\mathrm{a}}$ & $120.04(4.00)^{b}$ \\
\hline $\begin{array}{l}\text { Food securityt }(\%, \mathrm{Cl}) \\
\text { - Food secure } \\
\text { - Moderately food insecure } \\
\text { - Severely food insecure }\end{array}$ & 5412 & $\begin{array}{l}38.3(36.9-39.7) \\
39.8(38.4-41.2) \\
21.9(20.7-23.1)\end{array}$ & $\begin{array}{l}37.1(35.3-38.9)^{a} \\
41.1(39.3-42.9) \\
21.8(20.2-23.3)\end{array}$ & $\begin{array}{l}37.8(35.2-40.5)^{a} \\
39.3(36.6-42.0) \\
22.9(20.5-25.2)\end{array}$ & $\begin{array}{l}47.4(42.8-52.1)^{b} \\
33.0(28.6-37.3) \\
19.6(15.9-23.2)\end{array}$ \\
\hline
\end{tabular}

$*=$ ANOVA shows a significant difference among groups at $P<0.001$

$\mathrm{t}=\chi^{2}$ is significant at $\mathrm{P}<0.01$

Superscripts $\mathrm{a}, \mathrm{b}$ and ${ }^{\mathrm{c}}$ designate significant pairwise differences $(P<0.01)$ using Bonferroni adjustment method

$\mathrm{CI}=95 \%$ confidence interval, $\mathrm{SD}=$ standard deviation

₹ food-related assets scale is based on the ownership of an oven, microwave, refrigerator and freezer, with each asset contributing one point to the scale (score 0-4) 
Table 3. Weighted characteristics of older adults (aged 60 and over), and those living in

multigenerational households with at least one older adult and in households of older adult living alone, with spouse or with another older adult (single households)

\begin{tabular}{|c|c|c|c|c|}
\hline & \multirow[b]{2}{*}{$\begin{array}{l}\text { All older adults } \\
(n=2663)\end{array}$} & \multicolumn{2}{|c|}{ Living Arrangements } & \multirow[b]{2}{*}{$\begin{array}{l}P \text { value for } \\
\text { difference by } \\
\text { living } \\
\text { arrangement }\end{array}$} \\
\hline & & $\begin{array}{l}\text { Older adults in Multigenerational households } \\
(\mathrm{n}=1938)\end{array}$ & $\begin{array}{l}\text { Older adults in Single Households } \\
(\mathrm{n}=725)\end{array}$ & \\
\hline Age (mean, (SD)) & $69.7(0.16)$ & $69.1(0.18)$ & $71.3(0.31)$ & $<0.0001$ \\
\hline Gender (\% men, $(\mathrm{CI}))$ & $41.6(39.6-43.7)$ & $44.0(41.6-46.4)$ & $35.2(31.4-39.0)$ & 0.0002 \\
\hline Marital status (\% married, (CI)) & $63.2(61.2-65.2)$ & $65.2(62.8-67.5)$ & $58.1(54.2-62.0)$ & $<0.010$ \\
\hline $\begin{array}{l}\text { Educational attainment }(\%,(\mathrm{CI})) \\
\text { - None/didn't complete primary } \\
\text { - Completed primary } \\
\text { - Above primary level }\end{array}$ & $\begin{array}{l}69.0(67.1-71.0) \\
6.3(5.3-7.3) \\
24.7(22.9-26.5)\end{array}$ & $\begin{array}{l}67.9(65.6-70.1) \\
6.9(5.6-8.1) \\
25.3(23.2-27.4)\end{array}$ & $\begin{array}{l}72.3(68.7-75.9) \\
4.7(3.0-6.3) \\
23.0(19.6-26.4)\end{array}$ & 0.064 \\
\hline Employed (\% yes, $(\mathrm{Cl}))$ & $13.9(12.1-14.9)$ & $15.2(13.5-17.0)$ & $8.8(6.5-11.0)$ & $<0.0001$ \\
\hline $\begin{array}{l}\text { Chronic diseases, at least one (\% yes, (CI)) } \\
\text { - Hypertension } \\
\text { - Diabetes }\end{array}$ & $\begin{array}{l}86.1(84.6-87.5) \\
55.0(52.9-57.0) \\
32.8(30.9-34.8)\end{array}$ & $\begin{array}{l}85.4(83.7-87.1) \\
54.4(51.9-56.8) \\
33.1(30.8-35.3)\end{array}$ & $\begin{array}{l}87.7(85.2-90.3) \\
56.7(52.8-60.6) \\
32.3(28.6-36.0)\end{array}$ & $\begin{array}{l}0.154 \\
0.326 \\
0.727\end{array}$ \\
\hline Acute illness (\% yes, (CI)) & $55.3(53.4-57.3)$ & $54.9(52.5-57.2)$ & $56.6(52.7-60.5)$ & 0.463 \\
\hline Disability (\% yes, $(\mathrm{CI}))$ & $17.9(16.3-19.4)$ & $17.0(15.2-18.7)$ & $20.2(17.1-23.4)$ & 0.072 \\
\hline
\end{tabular}

Percentages given are based on sampling weight. CI= $95 \%$ confidence interval, $\mathrm{SD}=$ standard deviation 
Table 4. Multivariate logistic regression of food insecurity (score 2-6 versus 0-1) on demographic and socioeconomic factors of 2368 adults aged 60 and above

\begin{tabular}{|l|c|c|}
\hline \multicolumn{1}{|c|}{ Variables } & Odd Ratio & 95\% Confidence Interval \\
\hline Living arrangement & & \\
- Older adult living with family & 1.37 & $1.02-1.82$ \\
\hline Older adult living alone/with spouse or one other older adult (referent) & 1.00 & $0.97-1.00$ \\
\hline Age (years) & 0.98 & $0.66-0.97$ \\
\hline Gender (women vs men) & 0.80 & $1.27-2.20$ \\
\hline Educational attainment & & $0.72-1.70$ \\
\hline - Cone/didn't complete primary & 1.68 & $0.88-1.50$ \\
\hline - Above primary level (referent) & 1.11 & $0.52-0.75$ \\
\hline Marital status (Married vs single) & 1.00 & $1.58-2.64$ \\
\hline Food-related asset scale* (mean) & 1.15 & $1.44-2.38$ \\
\hline Poverty (yes vs no) & 0.62 & $1.13-2.02$ \\
\hline Welfare (yes vs no) & 2.04 & $1.19-1.89$ \\
\hline Chronic disease (yes vs no) & 1.85 & $0.63-1.04$ \\
\hline Acute disease (yes vs no) & 1.15 & 1.50 \\
\hline Receiving remittance from family or aid other than UNRWA (yes vs no) & 0.81 & \\
\hline
\end{tabular}

"food-related assets scale is based on the ownership of an oven, microwave, refrigerator and freezer, with each asset contributing one point to the scale (score 0-4)

Educational attainment was quite low in this older population with $69 \%$ not having received any formal education or not completing primary school. There were no significant differences in educational attainment by living arrangement. Employment was quite low in older adults (13.9\%) and significantly fewer older adults from single households were employed $(P<0.0001)$

The majority of older adults had at least one chronic condition (86.1\%) but there were no significant differences in prevalence by living arrangement. This was also true for acute illness whereby more than half of the older adults (55.3\%) reported at least an episode over the previous 6 months, but there were no significant differences in acute illnesses nor in disability by living arrangement.

\section{HOUSEHOLD FOOD INSECURITY}

Household food insecurity was highly prevalent in this population. Only $38.3 \%$ of all households were food secure, with $39.8 \%$ and $21.9 \%$ moderately and severely food insecure, respectively. However, food insecurity was significantly less prevalent in single households $(P<0.01)$ (Table 2$)$, and this remained true in the regression analysis even after controlling for confounders (Table 4). Additional covariates that were significantly and positively associated with household food insecurity included being poor, receiving welfare and having fewer food assets (Table 4). Also, being a man, of the young-old age, with chronic conditions or with an acute illness over the preceding 6 months were at greater risk of being in a food insecure household. However, receiving remittance from family or aid other than from UNRWA was not associated with food security although the inverse relationship approached significance (OR 0.81, 95\% confidence interval, $\mathrm{CI}=0.63-1.04$ )

\section{DISCUSSION}

There are limited studies that describe the living arrangements and characteristics of older refugee populations. This study specifically examines the characteristics of older Palestinian refugees in Lebanon, by living arrangements and, examines their food security status and its determinants. The results show that the majority of this population are unemployed, have low educational attainment and are at high risk of chronic disease and acute illnesses. This study also shows that older adults live predominantly in multigenerational households and although there is a high prevalence of poverty and food insecurity in all types of households, those who live in single households had lower prevalence of poverty and food insecurity and were the highest recipients of welfare and remittances. As expected, food insecurity was significantly associated with characteristics of vulnerability such as poverty, receiving welfare, but also with higher prevalence of chronic and acute illnesses.

Traditionally in the Arab world, as in many of the developing countries, family ties and structure are very strong and it is usual for multigenerational families to live together. ${ }^{2,5,13,14}$ Cohabitating with children provides reciprocal benefits to older and younger adults so that older parents benefit from financial support and in turn provide assistance in the form of household chores, childcare and life experiences. ${ }^{15,16}$ The proportion of Palestinian refugees in Lebanon who live in multigenerational households is similar to Palestinians living in the Occupied Palestinian Territories in 2007, where 73.4 and 62.2 percent men and women, respectively, lived in multigenerational households and in Jordan in 2012, 75.7 and 65.7 percent men and women, respectively, lived with their children. ${ }^{2}$ Although the pro- 
portion of older adults living with extended families varies by region, country, culture and economic conditions, there are more such living arrangements in developing countries than in Western ones. ${ }^{2,13,17}$ However, in the US, Wilmoth, Dejong and Himes ${ }^{18}$ reported that older immigrants of European, Latin American and Asian origin were significantly more likely than their native-born counterparts to live in extended families. Similarly, Boyd ${ }^{19}$ found that older adult immigrants tended to live with extended families but differences were observed based on country of origin and financial condition.

This representative sample of the protracted Palestinian refugee population in Lebanon is predominantly young with adults aged 60 years and older comprising $10.85 \%$ of the population. This age distribution is similar to that of the older Lebanese population which, in 2015, included $11.5 \%$ aged 60 and older. ${ }^{20}$ These proportions are lower than in most developed countries but considerably higher than the $4.5 \%$ in the Occupied Palestinian Territories ${ }^{20}$ and the $4.1 \%$ aged 65 and over in countries of the Arab region in $2010 .^{21}$ This may be an outcome of out-migration of the younger generations among both the Lebanese citizens ${ }^{22,23}$ and Palestinian refugees in Lebanon who left the country in search of economic opportunity. ${ }^{3}$

In this study, unemployment is quite high, particularly among older adults in single households. Considering that for Palestinian refugees in Lebanon, there is no pension or retirement plan (except for UNRWA staff) and level of education is quite low, so older adults must rely on their children and on welfare for financial assistance. A study conducted in 2000 of a representative sample of older adults in Amman, Jordan showed that the main sources of income for older adults was from children (41\%), followed by retirement or social security funds (36\%) and about $4.5 \%$ of them received assistance from neighbors and other relatives. ${ }^{24}$

We observed some significant differences in household characteristics and in individual characteristics of older adults by living arrangements. Overall, more than half of the Palestinian refugee households in Lebanon were poor. Although there was no significant difference in poverty between multigenerational households with or without residing older adults, those living in single households had a significantly lower prevalence of poverty. They also were the highest recipients of welfare and remittances from families and/or aid from agencies other than UNRWA. According to the 2010 UNRWA report, aid from non-UN sources was only received by $13 \%$ of the Palestinians, and many of these were infrequent and irregular. ${ }^{3}$ Based on the economic indicators of single households and on the older ages of their residents, we may surmise that if they had children, those would have been older, potentially working elsewhere and sending remittances back to the family. This financial assistance was reflected in lower risk of food insecurity, higher food expenditure, and a significantly lower share of total income spent on food. Although these households were at lower overall risk of food insecurity, still a fifth of the households were severely food insecure (19.6\%). This was higher than in a representative sample of a Southern Lebanese population where severe food insecurity was found in $10 \%$ of households. ${ }^{12}$ Although receiving welfare and remittances appear to provide relief to some families, this did not seem enough to eliminate food insecurity. Few studies examined the prevalence of food insecurity in older adult refugees in developing and developed countries. Of the studies that did examine food security of refugee populations, they were not age-specific, ${ }^{25-30}$ or the food security measures that were used varied. ${ }^{31,32}$ For example, Pieterse \& Ismail surveyed Rwandan refugees, ages 50-92 years, residing in Tanzania using 2 questions on dietary intake and reported that up to $90 \%$ of adults 70 years and older ate less than 3 meals per day and $86 \%$ did not eat enough. ${ }^{31}$ Also, Singh et al., found that men 45 years and older were more likely to report severe household hunger. ${ }^{32}$

Food insecurity is associated with poor diet quality ${ }^{8}$ and, exacerbates poor physical and mental health. ${ }^{33}$ As expected, in this study, health expenditure per person was significantly higher in households where only older adults reside. Poverty and food insecurity exacerbate chronic conditions, which are often costly to treat, partly because they require ongoing care and treatment for many years. ${ }^{34}$ Studies have shown that in the Arab region, older adults with chronic conditions were more likely to live at home and receive care from family members. ${ }^{35}$ However, with limited resources in the Palestinian camps and outmigration of children, it is unclear what the implications might be on the care of older adults. In our survey, there were no significant differences in the prevalence of chronic conditions, acute illnesses or disabilities by living arrangements, however, we did not have data to determine the severity of the reported conditions and level of physical dependence by living arrangements. Palestinian refugees in Lebanon who live in camps and surrounding areas live in close knit communities and are in close proximity to each other as the population density is quite high. ${ }^{36}$ Those who live alone may potentially have relatives and neighbors nearby to help out when needed. However, to develop appropriate interventions it is important to understand the resources needed by this population and their coping strategies.

Finally, our study, confirms findings from other published work in both developed and developing countries and shows that there are significantly more older women than older men and significantly more women who live alone. ${ }^{2} \mathrm{~A}$ study in Lebanon showed that older Lebanese women were 3 times more likely to live alone than older men. ${ }^{37}$ Women have a longer life expectancy than men and generally outlive their husbands which may result in more women living alone. In 2015, life expectancy of Palestinians in the Occupied Palestinian Territory was 70.7 and 74.7 in men and women respectively. In Lebanon it was 77.1 and 80.9 in men and women, respectively for the general population. ${ }^{20}$ As far as we know, there is no reported data on life expectancy of Palestinian refugees in Lebanon.

In summary, this study indicates that overall there is a high prevalence of poverty and food insecurity among Palestinian refugees living in Lebanon and there appears to be reliance of older adults on welfare from UNRWA and on remittances. UNRWA is currently experiencing a severe cut in funding which will potentially strain many of the services that are necessary for this age group such as healthcare and welfare. ${ }^{38}$ This could have dire consequences for Palestinian refugee families and the older adult population considering that they are already at high risk of poverty and food 
insecurity.

A limitation of this study is that these surveys were not intended to collect information specifically on older adults and so detailed information on this population is not available. In fact, few surveys collect data specifically on older adults and interventions do not often target this population. Interventions to eliminate poverty and food insecurity must take into account family dynamics and understand the role that older adults play in the household so that these interventions may be successful. Further research is necessary to understand the livelihood of those living in these households, their coping strategies and the reasons behind their living arrangements. This is also a particular issue for Palestinian refugees in Lebanon where resources for interventions are vastly limited due to their exclusion from national programs, and to the ever increasing funding shortages of the agency responsible for their welfare. Hence, future interventions would have to take into account this unique status.

Ethics: The research design for both surveys was approved by the Institutional Review Board of the American University of Beirut.

Funding: This study was supported by European Union grants to the United Nations Relief and Works Agency for Palestinian Refugees in the Near East (UNRWA).

Authorship contributions: NRS, HG conceived and designed the study, HG, AS conducted the study, NRS, AS, AV, FS, HG reviewed and analyzed the data, NRS, AV, HG wrote the paper.

Competing interests: The authors completed the Unified Competing Interest form at ww.icmje.org/coi_disclosure.pdf (available upon request from the corresponding author), and declare no conflicts of interest.

\section{Correspondence to:}

Nadine R. Sahyoun, PhD, RD

University of Maryland, Department of Nutrition and Food Science, 0112 Skinner Building College park, Maryland 20742

E-mail:nsahyoun@umd.edu 


\section{REFERENCES}

1. He W, Gookind D, Kowal P. U.S. Census Bureau, International Population Reports, P95/16-1. An Aging World: 2015, U.S. Washington, DC: Government Publishing Office; 2016. doi:10.1108/RR-08-2016-021 $\underline{2}$

2. United Nations. Department of Economic and Social Affairs, Population Division. World Population Ageing 2017 - Highlights (ST/ESA/SER.A/397). New York; 2017. https://www.un.org/en/development/des a/population/publications/pdf/ageing/WPA2017_High lights.pdf.

3. Chaaban J, Ghattas H, Habib R, Hanafi S, Sahyoun N, Salti N, et al. Socio-Economic Survey of Palestinian Refugees in Lebanon, Report published by the American University of Beirut and the United Nations Relief and Works Agency for Palestine Refugees in the Near East. 2010. https://www.unrwa.o rg/userfiles/2011012074253.pdf.

4. United Nations High Commissioner for Refugees. The State of the World's Refugees 2006: Human Displacement in the New Millennium. 2006. https://w ww.unhcr.org/en-us/publications/sowr/4a4dc1a89/sta te-worlds-refugees-2006-human-displacement-newmillennium.html. Accessed October 31, 2019.

5. Sibai AM, Yamout R. Family-Based Old-Age Care in Arab Countries: Between Tradition and Modernity. In: Groth H, Sousa-Poza A, eds. Population Dynamics in Muslim Countries. Berlin, Heidelberg: Springer Berlin Heidelberg; 2012:63-76. doi:10.1007/978-3-642-2788 $\underline{1-5} 5$

6. Rahim HF, Sibai A, Khader Y, Hwalla N, Fadhil I, Alsiyabi $\mathrm{H}$, et al. Non-communicable diseases in the Arab world. Lancet. 2014;383:356-367. doi:10.1016/S0 140-6736(13)62383-1

7. Roberts CK, Barnard RJ. Effects of exercise and diet on chronic disease. J Appl Physiol. 2005;98:3-30. do i:10.1152/japplphysiol.00852.2004

8. Hanson KL, Connor LM. Food insecurity and dietary quality in US adults and children: A systematic review. Am J Clin Nutr. 2014;100:684-692. doi:10.3945/aicn.114.084525

9. Food and Agriculture Organization. The State of Food Insecurity in the World 2001. Rome, Italy; 2001.

10. Sibai AM, Rizk A, Costanian C, Beard JR. Landscape of Research on Older Adults' Health in the Arab Region: Is It Demography-Driven or Development-Dependent? J Gerontol B Psy Sci Soc Sci. 2017;72:680-687.
11. Chaaban J, Salti N, Ghattas H, Irani A, Ismail T, Batlouni L. Survey on the Socioeconomic Status of Palestine Refugees in Lebanon 2015, Report published by the American University of Beirut and the United Nations Relief and Works Agency for Palestine Refugees in the Near East. 2016. https://reli efweb.int/sites/reliefweb.int/files/resources/surveon_t he economic_status_of_palestine_refugees_in_lebano n_2015.pdf. Accessed October 31, 2019.

12. Sahyoun NR, Nord M, Sassine AJ, Seyfert K, Hwalla N, Ghattas H. Development and validation of an Arab family food security scale. J Nutr. 2014;144:751-757. doi:10.3945/in.113.187112

13. Bongaarts J, Zimmer Z. Living arrangements of older adults in the developing world: An analysis of demographic and health survey household surveys. $J$ Gerontol B Psy Sci Soc Sci. 2002;57:S145-57:145-157. doi:10.1093/geronb/57.3.S145

14. Samanta T, Chen F, Vanneman R. Living arrangements and health in India. The Journals of Gerontology Series B: Psychological Sciences and Social Sciences. 2015;70(6):937-947. doi:10.1093/gero $\mathrm{nb} / \mathrm{gbu} 164$

15. Mehio-Sibai A, Beydoun MA, Tohme RA. Living arrangements of ever-married older Lebanese women: Is living with married children advantageous? J Cross Cultl Gerontol. 2009;24:5-17.

16. Ajrouch K, Yount KJ, Sibai AM, Roman P. A Gendered Perspective on Well-Being in Later Life: Algeria, Lebanon, and Palestine. (McDaniel SZ, Z., eds.). Farnham, UK: Ashgate Publishing; 2013.

17. Tomassini C, Glaser K, Wolf DA, Broese van Groenou MI, Grundy E. Living arrangements among older people: An overview of trends in Europe and the USA. Popul Trends. 2004:24-34.

18. Wilmoth JM, De Jong GF, Himes CL. Immigrant and non - immigrant living arrangements among america's white, hispanic, and asian elderly population. Int J Sociol Soc Policy. 1997;17:57-82. do i:10.1108/eb013325

19. Boyd M. Immigration and Living Arrangements: Elderly Women in Canada. Int Migr Rev. 1991;25:4-27. doi:10.1177/019791839102500101

20. United Nations. Department of Economic and Social Affairs, Population Division. World Population Ageing 2015 - Highlights (ST/ESA/SER.A/368). New York; 2015. 
21. Sibai AA, Kronfol KM. Ageing in the Arab Region: Trends, Implications and Policy Options. The United Nations Population Fund, Economic and Social Commission of Western Asia and the Center for Studies on Aging. Beirut, Lebanon; 2014.

22. Abdulrahim S, Ajrouch KJ, Antonucci TC. Aging in Lebanon: Challenges and Opportunities. Gerontologist. 2015;55:511-518. doi:10.1093/geront/ gnu095

23. Al-Khouri R. Arab migration patterns: The mashreq. In: International Organization for Migration. Arab Migration in a Globalized World. Geneva, Switzerland; 2004:21-34.

24. Mahasneh SM. Health perceptions and health behaviours of poor urban Jordanian women. J Adv Nurs. 2001;36:58-68. doi:10.1046/j.1365-2648.2001.0 1943.X

25. Hadley C, Sellen D. Food security and child hunger among recently resettled Liberian refugees and asylum seekers: A pilot study. J Immigr Minor Health. 2006;8:369-375. doi:10.1007/s10903-006-900 7-9

26. McKay FH, Dunn M. Food security among asylum seekers in Melbourne. Aust N Z J Public Health. 2015;39:344-349. doi:10.1111/1753-6405.12368

27. Roberts B, Felix Ocaka K, Browne J, Oyok T, Sondorp E. Factors associated with the health status of internally displaced persons in northern Uganda. $J$ Epidemiol Community Health. 2009;63:227-232. doi:1 0.1136/jech.2008.076356

28. Maharaj V, Tomita A, Thela L, Mhlongo M, Burns JK. Food Insecurity and Risk of Depression Among Refugees and Immigrants in South Africa. J Immigr Minor Health. 2017;19:631-637. doi:10.1007/s10903-0 16-0370-x

29. Banjong O, Menefee A, Sranacharoenpong K, Chittchang U, Eg-kantrong P, Boonpraderm A, et al. Dietary assessment of refugees living in camps: A case study of Mae La Camp, Thailand. Food Nutr Bull. 2003;24:360-367. doi:10.1177/156482650302400406
30. Anderson L, Hadzibegovic DS, Moseley JM, Sellen DW. Household food insecurity shows associations with food intake, social support utilization and dietary change among refugee adult caregivers resettled in the United States. Ecol Food Nutr. 2014;53:312-332. doi:10.1080/03670244.2013.831762

31. Pieterse S, Ismail S. Nutritional risk factors for older refugees. Disasters. 2003;27:16-36. doi:10.1111/ 1467-7717.00217

32. Singh KP, Bhoopathy SV, Worth H, Seale H, Richmond RL. Nutrition among men and household food security in an internally displaced persons camp in Kenya. Public health Nutr. 2016;19:723-731. doi:1 $\underline{0.1017 / \mathrm{S} 1368980015001275}$

33. Stuff JE, Casey PH, Szeto KL, Gossett JM, Robbins JM, Simpson PM, et al. Household food insecurity is associated with adult health status. J Nutr. 2004;134:2330-2335. doi:10.1093/jn/134.9.2330

34. Bloom DE, Chatterji S, Kowal P, Lloyd-Sherlock P, McKee M, Rechel B, et al. Macroeconomic implications of population ageing and selected policy responses. Lancet. 2015;385:649-657. doi:10.1016/S0 $\underline{140-6736(14) 61464-1}$

35. Abdelmoneium AO, Alharahsheh ST. Family home caregivers for old persons in the Arab region: Perceived challenges and policy implications. Open J Soc Sci. 2016;4:151-164.

36. United Nations Relief and Works Agency. Palestine Refugees. https://www.unrwa.org/palestin e-refugees. Accessed November 3, 2019.

37. Tohme RA, Yount KM, Yassine S, Shideed O, Sibai AM. Socioeconomic resources and living arrangements of older adults in Lebanon: Who chooses to live alone? Ageing and Society. 2011;31:1-17.

38. United Nations Relief and Works Agency Faces Greatest Financial Crisis in Its History Following 2018 Funding Cuts, Commissioner General Tells Fourth Committee [press release. United Nations. November 2018. http://www.un.org/press/en/2018/gaspd684.do c.htm. Accessed November 3, 2019. 